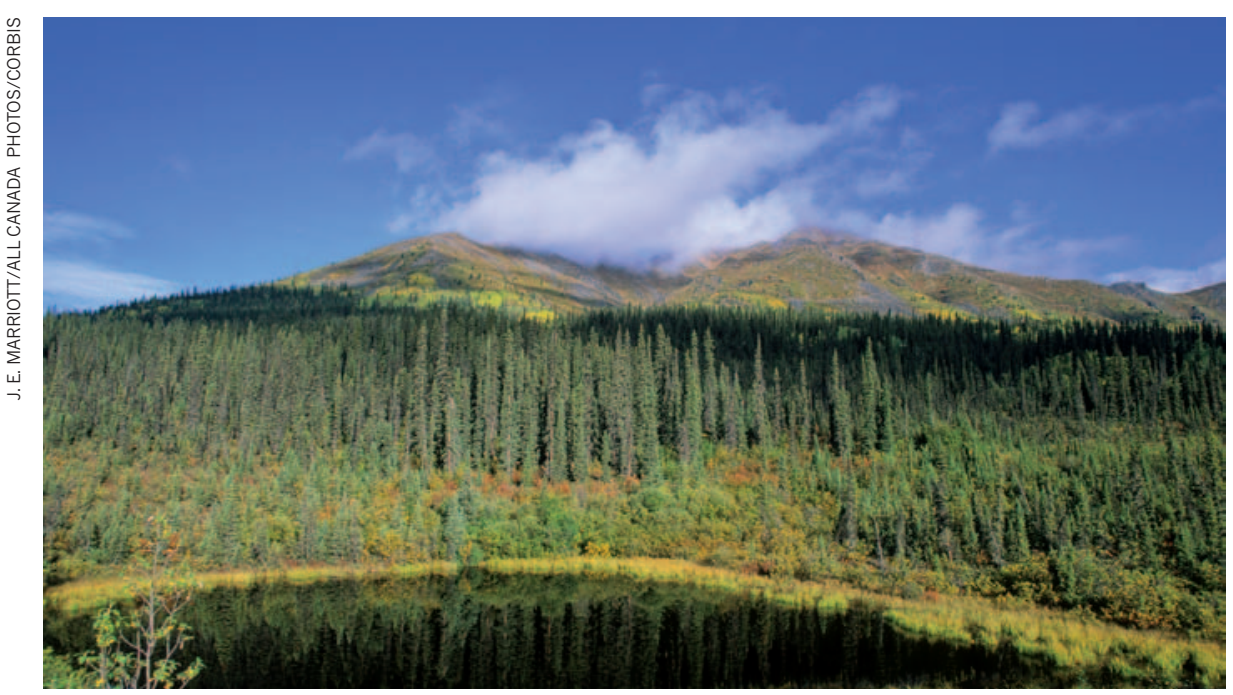

A year after it was unveiled, a landmark agreement to protect forests in Canada is not out of the woods.

\title{
CONSERVATION
}

\section{Canadian forest deal at risk}

\section{Pact to preserve vast swathe of wilderness faces reluctance from industry and resistance from native groups.}

\section{BY CHRISTOPHER PALA}

$\mathrm{F}$ or conservationists, the promise seems almost too good to be true - and some worry that it is. The Canadian Boreal Forest Agreement, a deal between the forestry industry and environmental groups, aims to set aside nearly 30 million hectares of northern wilderness and subject a further 42 million to strict tree-harvesting standards.

Unveiled in May 2010 (see Nature 465, 279; 2010), it would be the single biggest forestprotection deal ever, and has been portrayed by participants as a model of cooperation. At a briefing sponsored by the Canadian Embassy in Washington DC on 9 March, Avrim Lazar, president of the Forest Products Association of Canada in Ottawa, lauded former antagonists for "working together on how to meet the needs of humanity without trashing the environment, our own nest".

But those close to the negotiations say that the agreement may fall short of its bold vision. With timber companies reluctant to forgo extensive logging rights, and environmentalists adamant that far-reaching protections must be enforced, questions remain over how much forest will actually be preserved. Meanwhile, Canadian aboriginal groups, who were left out of the dealmaking process, are threatening to derail it.
"There are differences of expectations that will have to be reconciled," says Lorne Johnson, co-chairman of the Canadian Boreal Forest Agreement's secretariat in Ottawa, the body charged with implementing the plan.

Under the agreement, 21 forestry companies and 9 environmental groups are discussing ways to preserve large sections of Canada's northern forest - a big storehouse of carbon and a crucial habitat for the threatened woodland caribou (Rangifer tarandus caribou) - without diminishing lumber and pulp production. The companies that hold the rights to log roughly one-quarter of Canada's boreal forest have agreed to discuss giving them up in some unspecified areas; in exchange, the environmental groups have stopped urging buyers to boycott the companies' products. The parties now have one year left to make significant progress on two decision tracks.

In the first track, working groups of company officials and environmentalists in seven provinces are trying to identify areas of caribou habitat to be removed from logging plans. The negotiators will then lobby the aboriginal and provincial governments who have jurisdiction over the regions to turn them into national or provincial parks. "We expect to have draft conservation plans ready to show the provincial and First Nation governments in Quebec, Ontario and probably Alberta by June," says Johnson.

In the other track, a three-man panel of forestry auditors is developing new harvesting standards for the remainder of the land. Those standards, which include better mimicking of the natural cycles of forest regeneration through fire and insects, would make the wood produced there "the most environmentally preferable" in the world, said Steven Kallick, director of the International Boreal Conservation Campaign of the Pew Environment Group in Philadelphia, Pennsylvania, at the Washington briefing.

But disagreements have plagued both tracks. Richard Brooks, forests campaign coordinator at Greenpeace Canada in Toronto, who also spoke at the Washington meeting, has said that the agreement "means upwards of 20 million hectares of caribou habitat need to be conserved". But François Dumoulin, forestry director of AbitibiBowater in Montreal, one of Canada's largest wood products companies and an industry participant in the agreement, rejects that interpretation. "We never agreed to that," he says. "What we agreed to do is to increase the protected areas in the caribou range in ways that won't disrupt the work of our mills." Dumoulin says that it is too early to predict how much land will be set aside, "but it obviously won't be close to the total 29 million hectares of caribou habitat".

The original agreement pledged to respect "the principles of ecosystem-based management", an approach that takes into account human needs as well as ecological concerns. This would include the needs of aboriginal communities and others who are economically tied to the forest, such as trappers and tourism organizations. But some forestry companies oppose that approach, saying that it infringes on their flexibility, and no decision has yet been taken as to whether people will be included in the agreement's standards. Brooks says that the final plan must respect "all aspects including human ones" of ecosystem-based management. "If not, the agreement will not be successful," he says.

Aboriginal groups are unhappy that they have not been included in the dialogue. In December, a special assembly of First Nation chiefs voted to "reject and demand the termination" of the agreement, signalling a major obstacle to the deal in portions of the boreal forest for which aboriginal communities have jurisdiction. Russell Collier, who works for the agreement's secretariat, says that it was a mistake to leave the First Nations out of the talks, but adds that "an overlap of goals" could still bring native communities on board.

Others hope that the plan will survive, even if in a diminished form. "This is a framework on its way to becoming an agreement," says Todd Paglia, head of ForestEthics in San Francisco, California, another participating group. "What that destination ends up looking like is still in the air." - 